\title{
The Civil Rights Origins of Illegal Immigration
}

\author{
Mae M. Ngai \\ Columbia University
}

\begin{abstract}
The present immigration system is based on a core paradox. The method of allocating visas for the admission of permanent residents is based on principles of equality and fairness because all countries have the same quota. Yet visa demand varies widely. The principle of formal equality has disparate effects, being inclusionary for some and exclusionary for others. Four countries persistently max out on their caps-China, India, Mexico, and the Philippines-leading to long waits, easily ten to twenty years or more, and hence pressures for unlawful entry. The system generates an ever-larger caste-population of unauthorized immigrants.
\end{abstract}

The discussion of immigration reform in the United States since the 1980s has revolved around three main policy concerns: legalization, enforcement, and temporary workers - all aimed at grappling with the problem of unauthorized migration that has burgeoned since 1970. It is now estimated that twelve million people in the United States, one-third of the total foreign-born population, lack legal status. ${ }^{1}$ Proponents of immigration reform advocate a "comprehensive" approach that aims to resolve the problems caused by previous unauthorized entries and to deter future ones; this is also seen as a compromise between liberal and conservative interests (legalization versus enforcement). The proposal for guest or temporary workers does not cut across traditional party lines and is highly controversial, yet it is also the only proposal for addressing the demand for unskilled labor.

The current approach to reform reflects present US political alignments and predicaments, but I want to suggest that it does not address basic design flaws in the US immigration system and therefore is unlikely to resolve the problem. The debate over legalization versus enforcement also fuels an incendiary political discourse and leads to political deadlock. We need to go back to the basics, rethink the premises of US immigration policy, and think outside the box about other kinds of policy options. This will not be easy, but it is necessary if we are to achieve reform that is truly comprehensive and fair.

The problem of our present system is that it is based on a core paradox: Our system of allocating visas for the admission of permanent residents-the vaunted green card-is based on principles of equality and fairness, yet that very system has generated an ever-larger caste-population of unauthorized immigrants.

I want to first explain briefly how this paradox operates and then talk about its history and how thinking about history might offer a way forward. The current system, enacted by the 1965 Hart-Celler Act, provides for a global 
ceiling on annual immigration, with visas distributed according to seven preference categories (based on family relations and employment), and with every country having the same maximum number of visas per year. In 1965 the global ceiling was 290,000, and the country cap was 20,000 (phased in for the Western Hemisphere by 1976). Today the global ceiling is 226,000 for family categories and 140,000 for employment-based visas, and the country limit, seven percent of the total, is 25,620. (Family-based immigration is actually higher because immediate relatives - spouses, children, and parents of US citizensare not subject to numerical limitations.)

This system was deemed to be equitable and fair because it treats all countries the same, subjecting all to the same quotas and preferences. In practice, however, visa demand varies widely against an unchanging supply. Four countries persistently max out on their caps: China, India, Mexico, and the Philippines. When people say "you should get in line and wait for your visa," they do not understand that the wait can easily be twenty years or more.

To illustrate, let us look briefly at one category, First Preference (unmarried adult sons and daughters of US citizens). For countries other than the four mentioned, the visa backlog is six years: In November 2009 the State Department was processing visas for people who applied for admission in October 2003. But for Mexico, the cutoff date was July 1, 1992, meaning these prospective immigrants have waited sixteen and a half years to get to the front of the line. For Fourth Preference (adult siblings of US citizens) from the Philippines, the visa backlog is almost twenty-three years (cutoff date as of November 2009 was January 15, 1987). ${ }^{2}$

But it is actually more complicated. What about a person in Mexico who applied for a First Preference visa in 1995-how long is her wait? She has already waited fourteen years, and it would appear that she has to wait three more (1995-1992), for a total of seventeen years. But that would only be the case if the cutoff date advanced in real time. In fact, it does not. In November 2002 the cutoff date was November 1991. In the seven years since, the cutoff date advanced only eight months. ${ }^{3}$ That is a rate of advance of 1.14 months per year, and at that rate, the person who applied in 1995 will have to wait 31.5 more years, in addition to the fourteen years she has already waited. Extending this logic ad absurdum, we could state that at the current rate of advance, someone who applied for a visa in 2009 faces a potential wait of 173.25 years $(16.5 \times 10.5)$.

Of course, we do not know what cutoff date the State Department will set in the months and years to come. In practice, it has moved the date forward by a week or a month; sometimes it stays the same for months on end; sometimes it is even set back. For purposes of this exercise we can only use the current rate of advance, which I determined for the last seven years from the data available online. The point is that prospective immigrants from each of these four countries understand that waiting patiently in line likely means waiting twenty, thirty years, even a lifetime. For immediate family members of legal permanent residents, the wait is six years from Mexico and four years from other 
countries - not as long as the other categories, but because this category pertains to spouses and minor children, a five-year separation is a great hardship and particularly damaging for children. It is no wonder that many choose to risk entering surreptitiously, or with faked claims or identities, or by overstaying on nonimmigrant visas.

We rarely, if ever, question the principle embedded in Hart-Celler that we should treat every country the same. It is based on a logic of equality and fairness and was meant to replace the patently inequitable and discriminatory system of national origin and racial quotas that had governed immigration policy since the $1920 \mathrm{~s}^{4}$ It was also very much in line with the outlook of the civil rights era. That was the ethos of the time-Hart-Celler is often recalled as being of a piece with the Civil Rights Act of 1964 and the Voting Rights Act of 1965. It was also the self-conscious strategy of immigration reformers in the 1950s and early 1960s who decried the national origins quota system for its discrimination against eastern and southern Europeans. Harvard historian Oscar Handlin, an advisor to Senator Herbert Lehman on immigration reform during the 1950s, placed the question squarely in these terms. The quota system, he wrote,

cast[s] the slur of inferiority [upon] ... the grandfathers of millions of Poles and Italians and Jews, and of hundreds of thousands of others who, by their contributions to American life, have earned the right to be counted the equals of the descendants of the Pilgrims... The Italian American has the right to be heard ... precisely as an Italian American. The quotas implicitly pass a judgment upon his own place in the United States. ${ }^{5}$

Throughout the immigration debates of the late 1950s and early 1960s, reformers emphasized the symbolic nature of reform. The national origin quotas were a vestige of racism; a "slur" against American Jews, Italians, and Poles, and only secondarily a matter of actual immigration, since European immigration had steadily declined after the Second World War. For Handlin and Lehman and others, the equal participation of Euro-American ethnics in politics was the goal. They were not, at the time, thinking much about Asians or Latinos. Immigration policy for Asians was considered in terms of cold war foreign policy (the quota system was, Handlin said, "offensive to our allies and potential allies throughout the world"); Latinos were not seen as immigrants who crossed an ocean to settle permanently but as hemispheric neighbors who cycled in and out of the Southwest with each harvest season. Until the very last moment of negotiations over Hart-Celler, immigration reformers upheld continuing the policy of exempting the Western Hemisphere countries from numerical limits; the exemption had been in place ever since the 1920 s, when numerical limits were first imposed.

To policymakers in the 1960 s, the symbolic nature of reform easily led to a structure that was also heavily symbolic: Treat all countries the same. This was the logic of formal equality, which paid no heed to issues of substantive 
inequalities in the world's distribution of wealth and population and the actual requirements of fairness. But we might ask why, indeed, should New Zealand and Belgium have the same limits as Mexico and India?

The argument for equal rights in immigration policy, however, is a muddle. The rights-bearing subject is at once the American citizen; the countries of the world; and (possibly) the prospective migrant. Each set of rights derives a different epistemology: the civil rights of the American citizen; the right of nations to self-determination and equal standing in the world community; and the human rights of the individual migrant without regard to state membership. In the immigration reform discourse and legislation of the time, the first two principles were conflated at the cost of the third.

In 1963 Senator Philip Hart of Michigan introduced the immigration reform bill that would finally be enacted in 1965, bearing his name along with that of Emanuel Celler, New York City's longtime champion of immigrants. Hart did so at the behest of the Kennedy administration. In fact, Hart had, since 1961, introduced legislation of a very different nature, bills that had broad support but were ultimately swept aside by the administration's bills. In Hart's original bills, a total annual ceiling was set at 250,000 but, following tradition, exempting from the limit the countries of the Western Hemisphere. Of that 250,000, he allocated twenty percent for refugees and the balance to countries in proportion to the size of their population (thirty-two percent) and in proportion to their previous emigration to the United States (forty-eight percent). Under his plan, the only country that would have received a smaller quota than under the national origins system was Great Britain.

I call attention to Hart's bill not because I think we should imitate it but to make the point that there are other methods of allocating green cards. What is most noteworthy about Hart's proposal, in my view, is that it did not consider the United States' national interest in zero-sum opposition to the interests of other countries. It took into account a variety of factors-human rights, the needs of sending countries, historical regional ties in the Americas, and American citizens' familial ties abroad. It was thoughtful policy that tried to balance myriad interests and needs. ${ }^{6}$

Shortly after he introduced his bill in 1963, Hart was pressured to sponsor the Kennedy administration's bill. The latter was less generous in important respects: It gave only five percent to refugees and placed a uniform cap on visas for all countries, establishing the principle of "equal treatment" that would justify elimination of the Western Hemisphere exemption from numerical quotas. The principle also gave the bill a simplicity that was easy to argue for and easy to grasp under the rubric of civil rights.

Neither bill was reported out of committee before President Kennedy's death. The bill was bequeathed to the Johnson administration and passed by Congress in 1965, in the wake of the Civil Rights Act of 1964 and the Voting Rights Act of 1965, securing its status as a civil rights reform. When President Lyndon Johnson signed the bill at the foot of the Statue of Liberty, he declared that the new law "repair[s] a very deep and painful flaw in the fabric of 


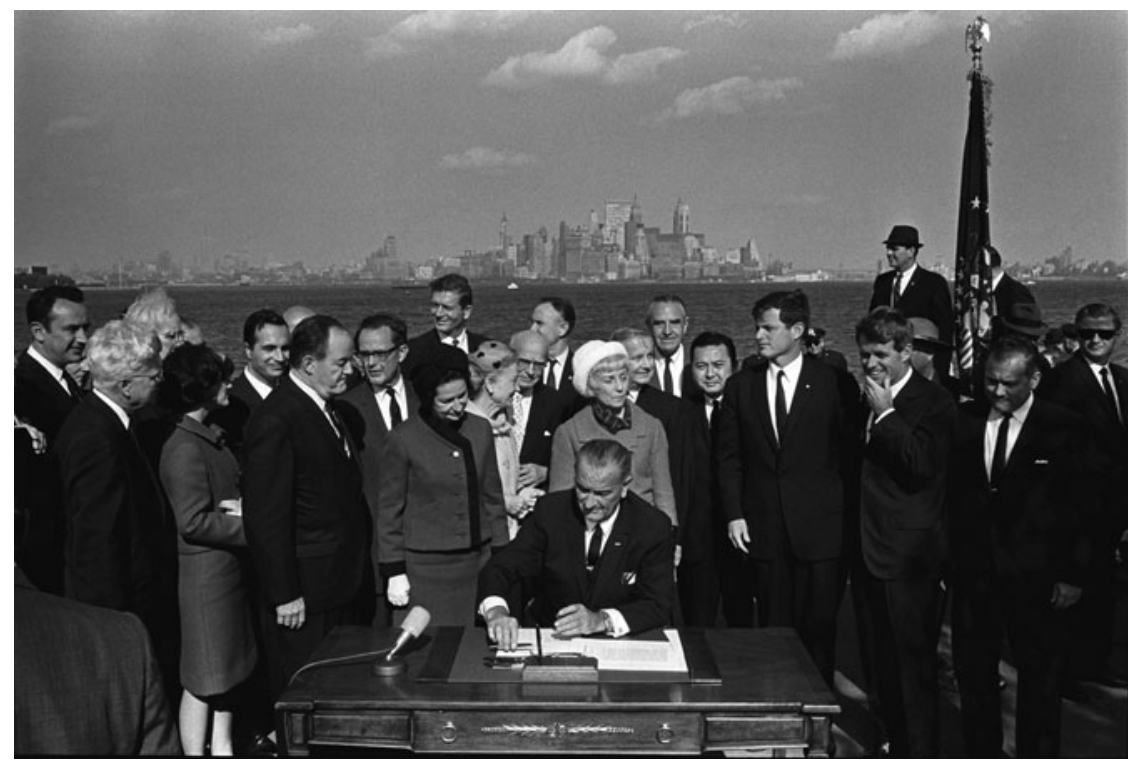

Figure 1. President Lyndon B. Johnson signs the Hart-Celler Act in October 1965. The law established the principle of "equal treatment" in the US immigration system, but it led to an increase in migration deemed illegal. Photograph by Yoichi R. Okamoto, courtesy of LBJ Library.

American justice." Immigration law now, he said, "says simply that from this day forth those wishing to immigrate to America shall be admitted on the basis of their skills and their close relationship to those already here," consistent with the democratic tradition that "values and rewards each [person] on the basis of his merit[.]"7

Hart-Celler's imposition of numerical quotas on countries of the Western Hemisphere had the immediate and long-lasting effect of generating ever greater numbers of unauthorized entries from Mexico. This consequence was not unforeseen; policy makers knew that placing a 20,000 annual limit on Mexican immigration was problematic. It had been just recently, in 1964, that the Bracero Program was terminated. That program had sponsored some four million temporary agricultural labor contracts for Mexican nationals since 1943. In the early 1960s there were still more than 200,000 Mexicans entering the United States on bracero contracts each year, as well as large numbers of people who came in a parallel stream of unauthorized migration. Congress terminated the program in 1964, citing exploitation and abuse as well as adverse effects on domestic farm workers; but the imposition of numerical quotas in 1965 meant there were no legal channels for Mexican migration beyond the 20,000 annual allotment. In the face of such a radical change, Congress implemented the country cap in the Western Hemisphere in phases, which took full effect in $1976 .{ }^{8}$ 
Illegal immigration from Mexico was not a new phenomenon after 1965. Under the 1924 quota law, Mexicans were not subject to numerical limits, but many continued to cross the border informally, as they had done in the past, in order to avoid expensive fees and degrading inspection procedures. In 1929, the State Department adopted an administrative policy of refusing visas to all laborers save for those with prior residence in the United States on grounds that they were liable to be public charges. The US-Mexico border developed over the course of the twentieth century as a border that was formally open and easy to cross but, paradoxically, easy to cross only without documents, indicating the United States' desire for Mexicans as a disposable labor force and not as immigrants and prospective citizens. The Bracero Program was based on the same logic.

When the initial hemispheric quotas under Hart-Celler went into effect in 1968, deportations to Mexico increased by forty percent, to 151,000. In 1976, when the country caps went into full effect, the United States deported 781,000 Mexicans. This compares with a total of 100,000 removals to all other countries in the world combined. By 1980 it was estimated that an illegal population of some two million people had accreted.

The legalization provision of the Immigration Reform and Control Act (IRCA) in 1986 legalized 2.6 million people. This achievement signaled the emergence of Latinos as a force in national politics and their success at coalition building with Asian Americans, African Americans, and religious and labor groups. The other provisions of IRCA that intended to stem future illegal entries-sanctions for employers who employed undocumented workers and increased border enforcement-did little to achieve their intended results. Employer sanctions were never enforced. The US-Mexico border has been steadily militarized since the late 1980s, with miles of fencing and walls, a doubling of the border patrol force, and the use of drones, stadium lighting, and motion detectors, by 2007, costing ten billion dollars a year. If these measures deterred some from unlawful entry, they pushed others to cross at more remote locations. By 2005 there were hundreds of migrants dying in the Arizona desert every year.

Migration from Mexico is driven by economic dislocations in Mexico (much of it resulting from the North American Free Trade Agreement [NAFTA]) and an insatiable demand for low-waged workers in the United States (agriculture, food processing, restaurants, service, and housing construction). But illegal migration from Mexico is a function of a system that limits, on principle, Mexico to the same number of annual visas as New Zealand. There are now some twelve million unauthorized migrants in the United States. Three-quarters of them are from Mexico and Central America. ${ }^{9}$ They are the direct beneficiaries of legislation passed in the era of civil rights, founded on the principle of formal equality.

In our present system and predicament, the principle of formal equality has disparate effects, being inclusionary for some and exclusionary for others. As long as this basic structural problem remains, we will continue in cycles of 
legalization and enforcement. We need to rethink not just the specifics, but the premises of our immigration policy.

\section{NOTES}

1. Jeffrey Passel, "A Portrait of Unauthorized Immigrants in the United States," Pew Hispanic Research Center, http://pewresearch.org/pubs/1190/portrait-unauthorizedimmigrants-states (accessed August 14, 2009).

2. US Department of State, Visa Bulletin Vol. 9, No. 14, November 2009, http://www.travel. state.gov/visa/frvi/bulletin/bulletin_4576.html (last accessed June 8, 2010).

3. US Department of State, Archived Visa Bulletins, 2002-2009, http://www.travel.state. gov/visa/frvi/bulletin/bulletin_1770.html (last accessed June 8, 2010).

4. The following discussion is based on Mae M. Ngai, "The Unlovely Residue of Outworn Prejudices': The Hart-Celler Act of 1965 and the Politics of Immigration Reform," in Americanism: New Perspectives on the History of an Ideal, ed. Michael Kazin and Joseph McCartin (Chapel Hill, NC, 2006).

5. Oscar Handlin, "The Immigration Fight has Just Begun," Commentary 14(July 1952). (2009).

6. Mae M. Ngai, "The Lost Immigration Debate," Boston Review, September/October

7. Johnson quoted in Mae M. Ngai, Impossible Subjects: Illegal Aliens and the Making of Modern America (Princeton, NJ, 2004), 259.

8. Ngai, Impossible Subjects, 261. Except where otherwise noted the following discussion draws from Impossible Subjects.

9. Passel, "Portrait of Unauthorized Immigrants." 